\title{
Lessons from COVID-19: The Perspective of an International Medical Student Back in the United States
}

Avnee Nulkar. ${ }^{1}$

\section{The Experience}

While applying to medical schools, I was advised to refrain from the "common cliché" - that helping people was my principle reason for aspiring to practice medicine. During interviews, I emphasized my fascination with the human body, my desire to bridge treatment and prevention, and my hope to lead the US' healthcare reform. Above all, I always circled back to my primary passion for impacting patients in a personally significant way - one that is only present in the field of medicine. The current pandemic, which has revealed the weaknesses in healthcare systems and highlighted the strength of healthcare workers globally, has re-affirmed my motivation for entering medical school and serving others.

I first learned of COVID-19 as an American student attending an Irish medical school. Quicker than expected, cases spread across the country, and the virus soon infiltrated our teaching hospitals. Within two weeks, we were quarantined and encouraged to return home. Since 2019 , I had meticulously planned my 2020, which I anticipated as the most important year of my career thus far. I was slated to complete US licensing exams and third-year medical school exams between March and May, and my US rotations would follow during Summer 2020. Instead, what initially appeared to be a contained virus evolved rapidly into a pandemic. Within days, my classmates and I returned to our home countries, with hopes of reuniting with our families and caring for our communities.

During my two-week self-isolation at home in California, my restless mind overwhelmed all rational sense. I was in limbo awaiting the decision to cancel or continue my US licensing exams, unsure how much study time to allocate towards my licensing exams versus medical school exams. I was also attempting to conceal my unremitting worry and fear for my family and friends, as the case number at home seemed to climb daily. More importantly, I felt, in the most realistic sense, useless. Here I was, with three years of medical knowledge, yearning to be helpful in hospitals, whether taking bloods, triaging patients, comforting families, or collecting personal protective equipment, yet a diploma was lacking - my perceived ticket into clinical settings to aid the fight against COVID-19 in California.

In time, I reframed these obstacles as challenges. I researched volunteer organizations in which I could deliver food to community members, tutor children, and foster shelter animals. Although my student status did not qualify me to aid in clinical settings, I was soon eligible to register with California Health Corps' COVID-19 Response Team and my local response team, thanks to Governor Gavin Newsom's appeal for increased aid.

While volunteering and awaiting my response call, I had time to reflect. This pandemic has revealed that the existing connection between healthcare and employment must be terminated. In $2012,61 \%$ of health insurance coverage was linked to employment, while $49 \%$ of coverage was employee sponsored in 2019.2,3 Although the percentage has decreased, too many Americans who experienced job security this past year are now unemployed, still resulting in loss of insurance.4.5 Compared to universal coverage, insufficient health coverage is associated with premature death and decreased health status, suggesting that the health of those who lose insurance is likely to suffer. ${ }^{6}$ Healthcare is a human right, not an employee benefit. The government should seize this opportunity to question the inner workings of our healthcare system and implement changes to prevent such losses in the future.

Contemplating the flaws in our current system has reiterated the significance of healthcare reform as well as strengthened my resolve for pursuing medicine. Doctors have a duty to care for their patients, which includes advocating for their right to access healthcare. Extra time, funding, and critical dialogue should be dedicated towards healthcare restructuring. Additionally, this pandemic has shed light on how grateful I am to have a home, healthy family members, and basic necessities. One month ago, my mind was consumed with exams and rotations. Now, I feel thankful for my family's safety and health and will do my best to advocate for patients' safety and health while refusing to take such comforts for granted.

Although I have yet to be called by the response teams, I recently learned that medical teams and volunteer organizations within California are reaching capacity. This news immediately filled me with gratitude. The inherent good of people in our community has provided a sense of unity and hope during a time of uncertainty and distress, inspiring me to provoke a similar feeling in those around me. The mode of doing so is irrelevant, whether it occurs in a clinical setting, from my desk at home, or in a car between food banks and homes. Personally and professionally, my purpose is to help people to the best of my ability - the "common cliché," or reason I pursued a medical career.

1 Medical student, University College Cork, Ireland.

About the Author: Avnee Nulkar is currently a 3rdyear medical student in a 4-year program at University College Cork in Cork, Ireland and a former undergraduate student at the University of California, Berkeley.

Correspondence:

Avnee Nulkar

Address: Gaol Walk, University College, Cork, T12 YN60, Ireland

Email: 117105068@umail.ucc.ie
Editor: Francisco J. Bonilla-Escobar Submission: Apr 22, 2020 Acceptance: Apr 27,2002 Acceptance: Apr 27, 2002 Publication: Apr 30, 2020
Process: Peer-reviewed 


\section{Experience}

\section{References}

1. Office of Governor Gavin Newsom. Governor Newsom announces California Health Corps, a major initiative to expand health care workforce to fight COVID19. Last updated: Mar 30, 2020; cited Apr 15, 2020. Available from: https://www.gov.ca.gov/2020/03/30/governor-newsom-announces-californiahealth-corps-a-major-initiative-to-expand-health-care-workforce-to-fight-covid19/.

2. Ridic $\mathrm{G}$, Gleason S, Ridic 0 . Comparisons of health care systems in the United States, Germany and Canada. Mater Sociomed. 2012;24(2):112-20

3. The Henry J. Kaiser Family Foundation. Health Insurance Coverage of the Tota Population. Last updated: Jan, 2019; cited Apr 15, 2020. Available from: https://www.kff.org/other/state-indicator/total-population/.
4. Tanne J, Hayasaki E, Zastrow M, Pulla P, Smith P, Rada A. Covid-19: how doctors and healthcare systems are tackling coronavirus worldwide. BMJ. 2020 Mar 18;368:m 1090.

5. King J. Covid-19 and the need for health care reform. N Engl J Med. 2020 Apr 17 [Epub ahead of print]

6. National Academies (US), Institute of Medicine (US), Woolf S ed, Aron L ed. U.S Health in international perspective: shorter lives, poorer health. Washington DC: National Academies Press; 2013. Cited Apr 16, 2020. Available from: https://www.ncbi.nlm.nih.gov/pubmed/24006554.

\section{Acknowledgments}

None

\section{Conflict of Interest Statement it Funding}

The Authors have no funding, financial relationships or conflicts of interest to disclose.

\section{Author Contributions}

Conceptualization, Writing - Original Draft and Writing - Review at Editing: AN.

Cite as:

Nulkar A. Lessons from COVID-19: The Perspective of an International Medical Student Back in the United States. Int J Med Students. 2020 Jan-Apr;8(1):7576.

This work is licensed under a Creative Commons Attribution 4.0 International License 